\title{
GEOECOLOGICAL FEATURES OF ZINC ACCUMULATION IN THE SOIL - PLANTS SYSTEM OF URBAN ECOSYSTEMS
}

\author{
PAVEL V. MASLENNIKOV
}

Institute of Living Systems, Immanuel Kant Baltic Federal University, Kaliningrad 236040, Str. Universitetskaya 2, Russian Federation.

*Corresponding author: PMaslennikov@kantiana.ru

Submitted final draft: 4 August $2020 \quad$ Accepted: 10 September 2020

http://doi.org/10.46754/jssm.2021.06.003

\begin{abstract}
The study aims to determine zinc accumulation in urban soil and in common urban landscape species of woodlands, bushes and herbaceous plants (22 species). Maximum metal concentration was observed in the soil of landscapes of industrial-utility and in residential multistore areas with increased transport load $\left(125.7-154.7 \mathrm{mg} / \mathrm{kg}^{-1}\right)$. Zinc $(\mathrm{Zn})$ content of plant leaves in urban areas depended on its concentration in soil ( $\mathrm{r}$ $=0.86-0.99, \mathrm{p}<0.05)$ and the vegetation period. The minimum $\mathrm{Zn}$ content in plant leaves was observed at the beginning of the growing season (May), and later with increasing age and leaf blade area, the metal concentration increased, reaching a maximum in October. The highest rates of metal bioaccumulation were found in Syringa vulgaris (1.24 $\%)$, Rosa rugosa $(1.17 \%)$ and Populus nigra $(1.1 \%)$. These species will be useful for phytoremediation of areas moderately polluted with $\mathrm{Zn}$. A decrease in $\mathrm{Zn} \mathrm{BAC}$ and an increase in its concentration in the soil were identified in the majority of plant species. Plant species capable of limiting the entry of $\mathrm{Zn}$ from the environment were also identified.
\end{abstract}

Keywords: Environmental contamination, zinc, phytoindication, phytourbocenosis, phytoremediation.

\section{Introduction}

One of the main environmental problems nowadays is pollution associated with rapid growth of cities. The concentration of industrial enterprises, heavy traffic and activities of public utilities have resulted in large industrial cities standing out against the natural background and becoming centers of environmental contamination (Chupakhina et al., 2017; Maslennikov et al., 2018). Each city is a unique techno-ecosystem, the components of which are under various anthropogenic pressures. The most dangerous environmental pollutants in cities are heavy metals (HMs) - when entering the biological cycle, they impose a number of negative effects on all natural components of the urban ecosystem's "air-soil-water-plants" (Clemens et al., 2002; Brezinova \& Vymazal, 2015; Chupakhina et al., 2017).

HMs can be subdivided into biogenic and toxicants. Such subdivision of is nominal, since different concentrations can cause both positive and negative effects on the body. Zinc (Zn) is an important nutrient that also belongs to the group of HMs. It plays a role in the metabolism of nucleic acids and proteins, besides stimulating and inhibiting the growth of plants (Rout \& Das, 2003; Lopez, 2005; Gupta et al., 2016). Zn acts as a cofactor for more than 300 proteins, the majority of which are zinc finger proteins, and also RNA and DNA polymerases (Lopez, 2005). It is the only metal present in all six enzyme classes (oxidoreductase, transferase, hydrolases, lyases, isomerases and ligases) (Nielsen, 2012; Gupta et al., 2016).

$\mathrm{Zn}$ is involved in a number of physiological processes of plants, such as hormone regulation (e.g. the synthesis of IAA precursor, tryptophan), signal transduction via mitogen-activated protein kinases (Lin et al., 2005; Broadley et al., 2007; Hansch \& Mendel, 2009; Gupta et al., 2016), repair processes of the PS II complex during photoinhibition (Bailey et al., 2002; Hansch \& Mendel, 2009; Gupta et al., 2016) and maintenance of $\mathrm{CO}_{2}$ concentration in mesophyll. Peck and McDonald (2010) confirmed the participation of $\mathrm{Zn}$ in the regulation of Rubisco activity, along with the reduction of adverse 
effects of heat stress on wheat (Peck et al., 2010; Sadeghzadeh, 2013).

There is a great difference between the required amount of $\mathrm{Zn}$ and its toxic level (Hambidge, 2000; White, 2012; Gupta et al., 2016). On one hand, lack of the element is a main agricultural problem today. In particular, $50 \%$ of the soil for cereal cultivation have $\mathrm{Zn}$ deficiency (Hotz \& Brown, 2004; Das \& Green, 2013). On the other hand, the accumulation of excess $\mathrm{Zn}$ will negatively affect soil processes. It changes the physical and physico-chemical properties of the soil and reduces its biological activity. $\mathrm{Zn}$ also inhibits vital activity of microorganisms (Hani \& Pazira, 2011; Olaniran et al., 2013; Sadeghzadeh, 2013), which leads to the disruption of organic matter formation in soil. Excess $\mathrm{Zn}$ in the soil cover hampers cellulose fermentation, respiration and urease activity (Vymazal \& Brezinova, 2015; Gupta et al., 2016).

The natural level of $\mathrm{Zn}$ in soil is determined primarily by its content in soil-forming rocks. The gross content of $\mathrm{Zn}$ in parent rocks of the Kaliningrad region is $9.7-46.5 \mathrm{mg} / \mathrm{kg}^{-1}$ and its average content in the Earth's lithosphere amounts to $83 \mathrm{mg} / \mathrm{kg}^{-1}$ (Kabata-Pendias, 2011; Gupta et al., 2016; Chupakhina et al., 2017; Maslennikov et al., 2018). The content in soil is also affected by their type and mechanical composition (Kabata-Pendias, 2011; Gupta et al., 2016; Chupakhina et al., 2017; Maslennikov et al., 2018). Zn content in sod-light podzolic soil ranges from $29.8 \mathrm{mg} / \mathrm{kg}^{-1}$ in sandy to 48.4 $\mathrm{mg} / \mathrm{kg}^{-1}$ in light loamy and $67.9 \mathrm{mg} / \mathrm{kg}^{-1}$ in medium loamy soils. Gross $\mathrm{Zn}$ amounts to 49.9 - $68.8 \mathrm{mg} / \mathrm{kg}^{-1}$ in light loamy and medium loamy soils. In humus-peat lowland and floodplain sod soils, it is $86.5-96.7 \mathrm{mg} / \mathrm{kg}^{-1}$ (Kabata-Pendias, 2011; Gupta et al., 2016; Chupakhina et al., 2017; Maslennikov et al., 2018).

In addition to soil, $\mathrm{Zn}$ can also accumulate in plants. Some fractions in soil exist either as an insoluble complex, or in adsorbed and exchangeable forms. However, other fractions exist in water-soluble form and are freely available to plants. Root activity also makes the exchangeable form partially available for uptake via ion exchange and release of organic acids etc. Insoluble $\mathrm{Zn}$ comprises $>90 \%$ of the metal in soil that cannot be utilized by plants, while the exchangeable form ranges from 0.1 to $2 \mu \mathrm{g} \mathrm{Zn} \mathrm{g}^{-1}$. Concentrations of water-soluble $\mathrm{Zn}$ range between $4 \times 10^{-10}$ and $4 \times 10^{-6} \mathrm{M}$ in bulk soil solution (Gupta et al., 2016). Soil moisture is another physical factor that affects $\mathrm{Zn}$ uptake by plant roots via diffusion. Role of soil moisture is very crucial in soil with low $\mathrm{Zn}$ availability (Gupta et al., 2016). Solubility of $\mathrm{Zn}$ and the ratio of $\mathrm{Zn}^{2+}$ to organic- $\mathrm{Zn}$ ligand complexes will especially increase at low $\mathrm{pH}$ for low soluble organic matter soil. Higher levels of soil organic matter will enhance the entry of phytoavailable $\mathrm{Zn}$ in soil (Catlett et al., 2002; Obrador et al., 2003). In addition to soil pH, soil redox potential (i.e. Eh) strongly influences the speed and intensity of humification process, redox status of the rhizosphere and the mobility of $\mathrm{Zn}$. In conclusion, soil type, mineral and clay types, soil biota and plant uptake will collectively determine $\mathrm{Zn}$ distribution in soilroot-plant fluxes.

A number of researchers have shown that the accumulation of $\mathrm{Zn}$ in the soil-plant system is a good tool for assessing environmental risk (Romero-Freire et al., 2016; Lago-Vila et al., 2017). Other authors suggest that mapping of the spatial distribution of zinc-polluted soil is necessary for human and ecological risk assessment (Hani \& Pazira, 2011; Delavar \& Safari, 2016; Baran et al., 2018). Guo et al. (2012) reported that information about the pattern of heavy metal distribution in soil with different land use may assist in developing strategies to protect the environment and human health against long-term accumulation of HMs.

Urbanized territories are under strong technogenic pressure and all natural components of the urban ecosystem undergo a number of changes and acquire features that distinguish them from their natural counterparts. This leads to deterioration in environmental quality (Chupakhina et al., 2017; Maslennikov, 2020). In the Russian Federation, monitoring studies 
are being conducted in many cities to assess the ecological status of natural components in the urban ecosystem. In the Kaliningrad region, such studies are sporadic in nature, lacking a common methodological base and certainly are in need of updating. For these reasons, studies assessing the ecological state of the natural vegetation of the urban ecosystem have a particular scientific and practical significance and relevance. The purpose of this study is to investigate the geoecological features of $\mathrm{Zn}$ accumulation in the soil system - plants in urban phytourbocenoses of the city of Kaliningrad, Russia. This study investigated the accumulation of $\mathrm{Zn}$ in the accumulative horizon of urban soil and in the most common types of trees, bushes and herbaceous plants in urban landscapes.

\section{Materials and Methods}

\section{Area Characterization}

The area under study comprised the main geochemical landscapes of Kaliningrad city, which were recreational zones (RecZ, control), agricultural/residential zones (ARZ), residential zones (RZ) and industrial/utility/transport zones (IUTZ) (Figure 1). Recreational landscapes within 40-50 km away from large industrial sources of pollution, and least affected by human and pollutants (Svetlogorsk), were used as the control area.

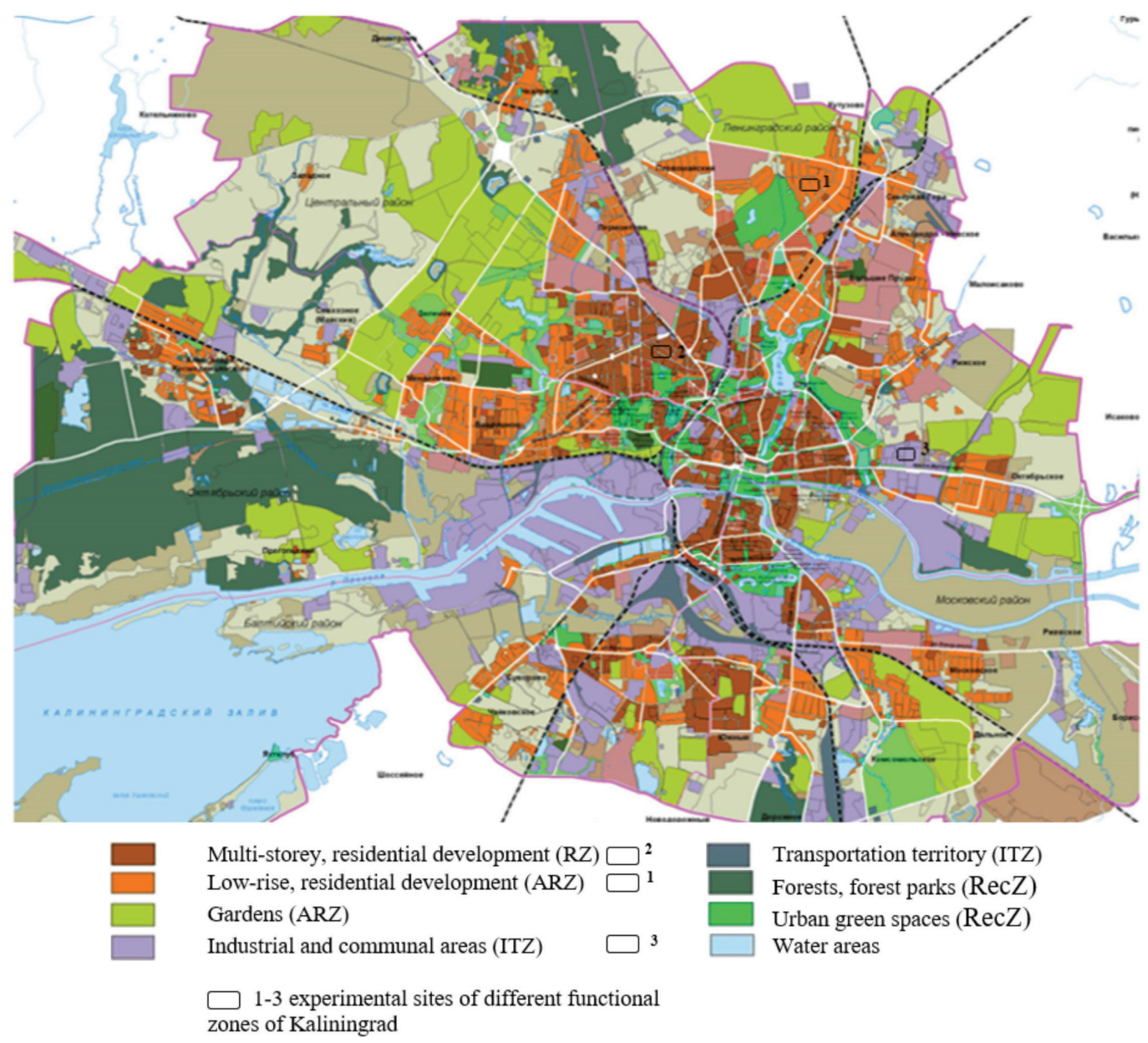

Figure 1: Functional zoning of Kaliningrad 
Residential areas occupied up to $27 \%$ of the city's territory (2,833 ha). Technogenic pedogeochemical anomalies were formed there, their contrast depending on the height and location of the facilities. Residential buildings served as a mechanical barrier to airflow and directly affected the characteristics of entry, movement, accumulation and removal of polluting chemicals (Maslennikov et al., 2018). The agro-residential landscape (ARL) included individual buildings combined with household plots (summer cottages, garden and kitchen-garden plots), and its share in the structure of urban areas was quite significant, which amounted to $15 \%$ (2,398 ha) of the city's landscape (Maslennikov et al., 2018). IUTZs occupied $15 \%$ of the urban area $(2,430 \mathrm{ha})$. Landscapes of enterprises were characterized by an extensive degradation of the biological cycle of substances and served as the source of anthropogenic emission and accumulation of pollutants (Maslennikov et al., 2018). RecZ landscapes were the least subjected to atmotechnogenic impact, since the role of biogenic migration in them was still profound. They amounted to $16 \%$ of the territory and were located in the city center and on the outskirts.

According to the redox conditions of HMs. RecZ, RZ and IUTZ sites were represented by geochemical landscapes with oxidative conditions, whereas ARZ sites were represented by landscapes with reducing conditions. The acid-base conditions of urban soil was slightly alkaline $\left(\mathrm{pH}_{\mathrm{KCl}} 7-8\right)$, but it was neutral in the control area ( $\mathrm{RecZ})\left(\mathrm{pH}_{\mathrm{KCl}} 6-7\right)$ (Maslennikov et al., 2018). As per geomorphological features of research sites, RZ soil was represented by transeluvial geochemical landscapes, IUTZ by trans-accumulative, and RecZ and ARZ by eluvial landscapes. Samples of the humusaccumulative horizon, which were selected around the city, were mainly sand or sandy loam by granulometric composition (Maslennikov et al., 2018).

\section{Material Collection and Heavy Metal Analysis}

$\mathrm{Zn}$ concentration was analysed in the tissues of the most common urban plant species (Table 2). Plant material was collected during the growing season from May to October 2018. In each functional zone, plant and soil samples were taken from three sites. Soil samples were collected from the topsoil at a depth of $0-10$ $\mathrm{cm}$, using the envelope method (Chupakhina et al., 2017; Maslennikov, 2020). In the study areas, we established permanent research sites with an area of $100 \mathrm{~m}^{2}$. The size of the zone from which the plant samples were collected corresponded to $1 \mathrm{~km}^{2}$. Zn concentration in the soil and plant samples was measured by X-ray fluorescence with the help of a Spektroskan Maks-G spectrometer (SPECTRON, Russia). Soil samples were prepared according to Chupakhina et al. (2017). Plant leaves were dried to a constant weight and ground to powder in a quartz mortar. The content of $\mathrm{Zn}$ in averaged samples was determined and expressed in $\mu \mathrm{g} / \mathrm{g}$ of dry weight (Chupakhina et al., 2017; Maslennikov, 2020). "Averaged" means that combined plant material was collected from six to nine individual plants at each of the three experimental sites in a functional zone under study. Each combined sample was analysed in triplicates.

In order to characterize the migration of biogenic zinc in the soil-plant system, the coefficient of biological absorption (CBA) was calculated on the basis of $\mathrm{Zn}$ gross content in soil and leaves. CBA is a biogeochemical indicator of the elements' biological absorption intensity by vegetation. According to the biological absorption intensity, all elements can be divided into the following categories: vigorous absorption elements $(\mathrm{CBA}=10-100)$; strong absorption elements $(\mathrm{CBA}=1-10)$; elements of weak absorption and average capture $(\mathrm{CBA}=$ 0.1-1.0); and, elements of weak capture (CBA $=0.01-0.10)$. When estimating the intensity of biogenic migration, plants were assumed to accumulate elements with a CBA of $>1$, as elements were only captured by plants with a CBA $<1$ (Chupakhina et al., 2017; Phetsombat et al., 2006). 
In the course of the study, 378 plant and 12 soil samples were analysed. Charts and tables were used to present the data in arithmetic means and standard errors of the mean. Statistical significance of differences between variants was established using Student's t-test $(p \leq 0.05)$. The figures show polynomial trend lines, degree - 2. Correlation analysis was conducted using Pearson's chi-squared test.

\section{Results}

\section{Zinc Content in Soil of Different Functional Zones}

Analysis of zinc content in the soil of various functional areas of the city showed that maximum metal concentration was observed in IUTZ landscapes and in residential multistore areas with increased transport load (154.7 \pm 11.8 $\mathrm{mg} / \mathrm{kg}-1)$. The concentration of zinc in the upper soil layer of such sites exceeded the background indicator 3.1 times. In ARZ and RZ, zinc content in the accumulative soil horizon exceeded the background indicator by 2.2 and 2.5 times, respectively (Table 1.). In general, the study revealed an excessive zinc accumulation in the accumulative soil horizon not only in relation to the background, but also to the approximate permissible concentration (APC) of metal (55 $\mathrm{mg} / \mathrm{kg}-1)$. Samples of all urban sites exceeded the standard between 2.0 and 2.8 times.

\section{Zinc Content in Plants of Different Functional Zones}

Urban ecosystems in Kaliningrad (which were used for biogeochemical monitoring) consisted of parks, housing area landscapes, lawns and road landscapes. These were mainly manmade systems (semi-cultivated, cultivated and ornamental) that were subjected to human impact. Plant composition of urban ecosystems was not very diverse and it was represented by lawn grasses and weed species, trees and shrubs that were traditionally used in city gardening.

This study analyzed the background levels of $\mathrm{Zn}$ in tree leaves, shrubs and herbaceous plants - the accumulation of the metal in the leaves in polluted areas and its change during the growing season. Analysis of $\mathrm{Zn}$ background levels in plants did not reveal statistically significant differences among the types of plants (trees, shrubs and herbaceous). Maximum metal content was observed in leaves of Populus nigra $(83.2 \pm 8.2 \mathrm{mg} / \mathrm{kg}-1)$ and Betula pendula $(57.3 \pm 5.6 \mathrm{mg} / \mathrm{kg}-1)$ in woody plants, in leaves of Sambucus nigra $(30.2 \pm 3.1 \mathrm{mg} / \mathrm{kg}-1)$ in shrubs and in leaves of Trifolium pratense (38.6 2.7 $\mathrm{mg} / \mathrm{kg}-1$ ) among grass species (Table. 2).

Table 1: $\mathrm{Zn}$ concentrations in the topsoil $(0-10 \mathrm{~cm})$ in different functional zones of Kaliningrad, $\mathrm{mg} / \mathrm{kg}-1$

\begin{tabular}{ccccc}
\hline \multicolumn{5}{c}{ Landscape type } \\
\hline $\mathrm{K}$ & $\mathrm{RecZ}$ & $\mathrm{ARZ}$ & $\mathrm{RZ}$ & $\mathrm{IUTZ}$ \\
$9.7-46.5$ & $49.4 \pm 0.5$ & $108.2 \pm 10.5^{*}$ & $125.7 \pm 12.6^{*}$ & $154.7 \pm 11.8^{*}$ \\
\hline
\end{tabular}

Note: RecZ stands for recreational zones (background), ARZ for agricultural/residential zones, RZ for residential zones, and IUTZ for industrial/utility/transport zones. $\mathrm{K}$ is the average element content in maternal rocks of the Kaliningrad region according to (Chupakhina et al., 2017; Maslennikov et al., 2018). Data are expressed as mean values \pm standard deviations. * Significantly different from control values $(\mathrm{RecZ})(\mathrm{p}<0.05$, Student's t-test). The content of elements was determined in mixed samples from three research sites of each functional area. Each combined sample was analysed using three analytical replications. Due to insignificant discrepancy between the analytical replicates, statistical processing of data was carried out only by taking into account biological replications $(n=3)$. 
Table 2: Zn concentrations in the leaves of woody, shrub and herbaceous plants in different functional zones of Kaliningrad.

\begin{tabular}{|c|c|c|c|}
\hline \multirow[b]{2}{*}{ Species } & \multicolumn{3}{|c|}{$\mathrm{Zn}, \mathrm{mg} / \mathrm{kg}^{-1}$} \\
\hline & RecZ & $\mathbf{R Z}$ & IUTZ \\
\hline \multicolumn{4}{|c|}{ Tree species } \\
\hline Populus nigra $\mathrm{L}$. & $83.2 \pm 8.2$ & $122.9 \pm 13.1^{*}$ & $148.6 \pm 14.3^{*}$ \\
\hline Betula pendula Roth & $57.3 \pm 5.6$ & $74.3 \pm 7.2^{*}$ & $81.2 \pm 8.1^{*}$ \\
\hline Acer platanoides $\mathrm{L}$. & $33.1 \pm 3.1$ & $35.5 \pm 3.6$ & $37.8 \pm 3.7$ \\
\hline Tilia cordata Mill. & $22.1 \pm 2.0$ & $24.2 \pm 2.3$ & $26.6 \pm 2.5$ \\
\hline \multicolumn{4}{|c|}{ Shrubs } \\
\hline Sambucus nigra L. & $30.2 \pm 3.1$ & $34.2 \pm 3.3$ & $32.4 \pm 3.3$ \\
\hline Symphoricarpos rivularis Suksdorf. & $24.6 \pm 2.5$ & $31.8 \pm 3.1$ & $37.8 \pm 3.8^{*}$ \\
\hline Syringa vulgaris L. & $24.2 \pm 2.3$ & $79.4 \pm 8.1^{*}$ & $94.5 \pm 9.3^{*}$ \\
\hline Viburnum opulus 'Roseum' & $24.4 \pm 2.4$ & $48.2 \pm 4.8^{*}$ & $69.7 \pm 6.8^{*}$ \\
\hline Ligustrum vulgare L. & $20.2 \pm 2.1$ & $23.7 \pm 2.2$ & $26.8 \pm 2.5^{*}$ \\
\hline Philadelphus coronarius L. & $19.7 \pm 1.8$ & $24.7 \pm 2.5$ & $30.9 \pm 2.9^{*}$ \\
\hline Ribes alpinum $\mathrm{L}$. & $19.6 \pm 1.9$ & $27.3 \pm 2.8^{*}$ & $38.5 \pm 3.8^{*}$ \\
\hline Spirae vanhouttei (Briot.) Zab. & $18.5 \pm 1.9$ & $20.3 \pm 1.8$ & $19.8 \pm 1.8$ \\
\hline Rosa rugosa Thunb. & $17.3 \pm 1.8$ & $63.7 \pm 6.4^{*}$ & $85.4 \pm 8.6^{*}$ \\
\hline Berberis vulgaris $\mathrm{L}$. & $17.1 \pm 1.7$ & $20.5 \pm 1.9$ & $24.6 \pm 2.4^{*}$ \\
\hline Hippophae rhamnoides L. & $14.1 \pm 1.4$ & $18.6 \pm 1.9$ & $21.6 \pm 2.1^{*}$ \\
\hline \multicolumn{4}{|c|}{ Herbs } \\
\hline Trifolium pratense $\mathrm{L}$. & $38.6 \pm 3.8$ & $58.1 \pm 5.7^{*}$ & $62.4 \pm 6.2^{*}$ \\
\hline Plantago major L. & $34.5 \pm 3.5$ & $36.3 \pm 3.5$ & $33.4 \pm 3.2$ \\
\hline Trifolium repens L. & $28.0 \pm 2.7$ & $34.7 \pm 3.4$ & $38.2 \pm 3.8^{*}$ \\
\hline Tanacetum vulgare $\mathrm{L}$. & $27.2 \pm 2.7$ & $42.4 \pm 4.1^{*}$ & $57.6 \pm 5.7^{*}$ \\
\hline Achillea millefolium $\mathrm{L}$. & $25.4 \pm 2.5$ & $41.0 \pm 4.1^{*}$ & $49.3 \pm 4.9^{*}$ \\
\hline Taraxacum officinale Wigg.s.l. & $23.1 \pm 2.3$ & $30.2 \pm 3.1$ & $34.7 \pm 3.4^{*}$ \\
\hline Dactylis glomerata $\mathrm{L}$. & $20.3 \pm 2.1$ & $23.2 \pm 2.4$ & $29.8 \pm 2.8^{*}$ \\
\hline
\end{tabular}

Note: RecZ stands for recreational zones (background), RZ for residential zones, and IUTZ for industrial/utility/transport zones. Data are expressed as mean values \pm standard deviations. * significantly different from control values $(\operatorname{Rec} Z)(p<0.05$, Student's t-test). The content of elements was determined in three mixed plant samples in three analytical replicates. Due to the insignificant discrepancy between the analytical replicates, statistical processing of data was carried out only by taking into account biological replications $(n=3)$.

$\mathrm{Zn}$ content in plants at contaminated zones (eg. IUTZ) varied from 19.8 to $148.6 \mathrm{mg} / \mathrm{kg}$. Metal content in the leaves of Syringa vulgaris under conditions of severe soil pollution in industrial-utility and transport landscapes (IutL) exceeded the background by 3.9 times, and in Rosa rugosa leaves by 4.9 times. In the leaves of Achillea millefolium, Ribes alpinum, Tanacetum vulgare and Viburnum opulus, $\mathrm{Zn}$ content was 1.9 to 2.9 times higher than in the background. Metal concentration exceeded the background by 1.3 to 1.8 times in the leaves 
of Ligustrum vulgare, Trifolium repens, Betula pendula, Berberis vulgaris, Dactylis glomerata, Hippophae rhamnoides, Taraxacum officinale, Symphoricarpos rivularis, Philadelphus coronarius, Trifolium pratense and Populus nigra. $\mathrm{Zn}$ accumulation was insignificant in the leaves of Tilia cordata, Acer platanoides, Spirae vanhouttei, Sambucus nigra and Plantago major.

The zinc content in the leaves of plants of urban ecosystems was studied during the growing season (May to October). The analysis of the metal accumulation dynamic showed that minimum $\mathrm{Zn}$ content in leaves was observed at the beginning of the season (May), and later increasing with the increase of age and leaf blade area, reaching its maximum in October. At the end of the season, in the leaves of woody plants (Populus nigra, Tilia cordata, Acer platanoides), $\mathrm{Zn}$ content had exceeded its initial level by 1.6 to 2.3 times (Figure 2).

In the leaves of shrubs (Sambucus nigra, Rosa rugosa and Hippophae rhamnoides), $\mathrm{Zn}$ content increased by an average of 2.5 to 3.7 times at the end of the growing season (Figure 3).

Among the herbaceous plants, zinc content in Tanacetum vulgare and Taraxacum officinale leaves exceeded the similar indicator in October by 2.6 to 3.2 times compared with the level in May. In the leaves of Trifolium repens, the increase was 1.5 times higher in the same period. It was only in Plantago major leaves that the metal content did not have significant changes during the growing season (Figure 4).

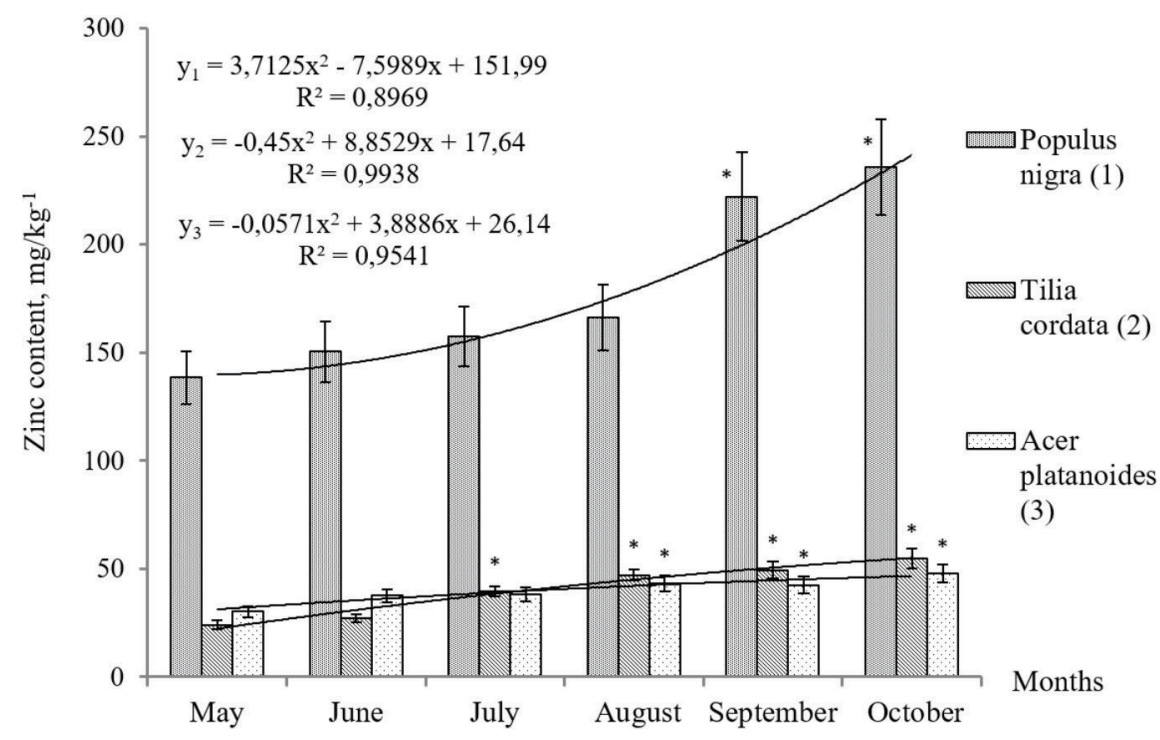

Figure 2: The zinc content in the leaves of woody plants during the growing season in 2018 (industrial/ transport landscapes). The abscissa axis shows the growing season, months; the ordinate indicates zinc content, $\mathrm{mg} / \mathrm{kg}^{-1} ;-$ is a polynomial trend lines, degree - 2. Data are expressed as mean values \pm standard

deviations. The content of elements was determined in three mixed plant samples in three analytical replicates. Due to the insignificant discrepancy between the analytical replicates, statistical processing of data was carried out only by taking into account biological replications $(n=3)$ * Significantly different from control values (May) $(\mathrm{p}<0.05$, Student's t-test). 


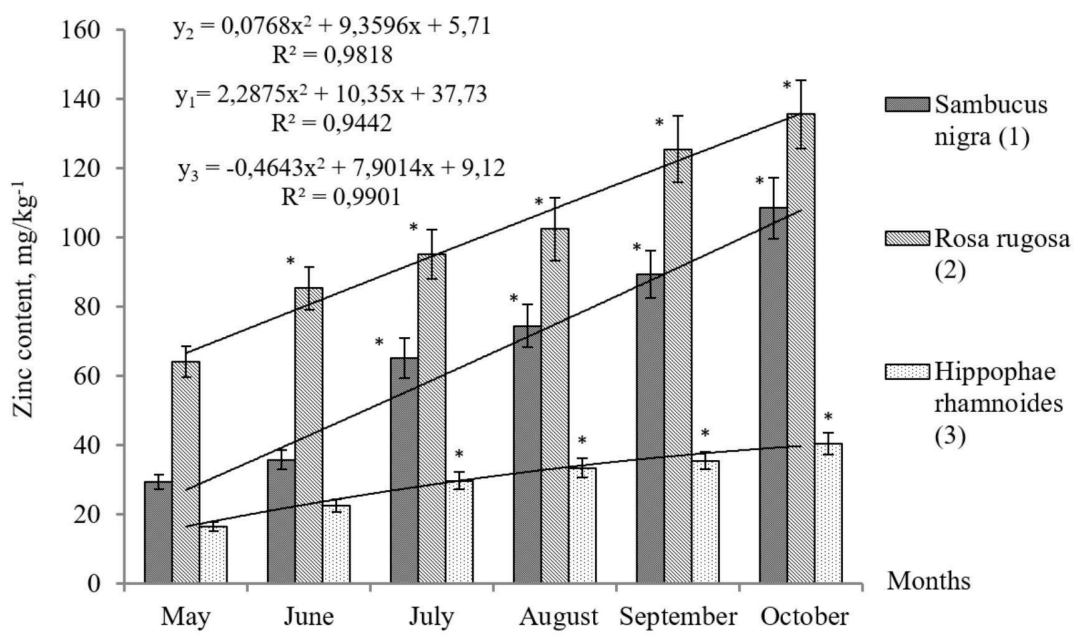

Figure 3: The zinc content in the leaves of shrub plants during the growing season in 2018 (industrial/ transport landscapes). The abscissa axis shows the growing season, months; the ordinate indicates zinc content, $\mathrm{mg} / \mathrm{kg}^{-1} ;$ - is a polynomial trend lines, degree -2 . Data are expressed as mean values \pm standard

deviations. The content of elements was determined in three mixed plant samples in three analytical replicates. Due to the insignificant discrepancy between the analytical replicates, statistical processing of data was carried out only by taking into account biological replications $(\mathrm{n}=3) . *$ significantly different from control values (May) $(\mathrm{p}<0.05$, Student's t-test).

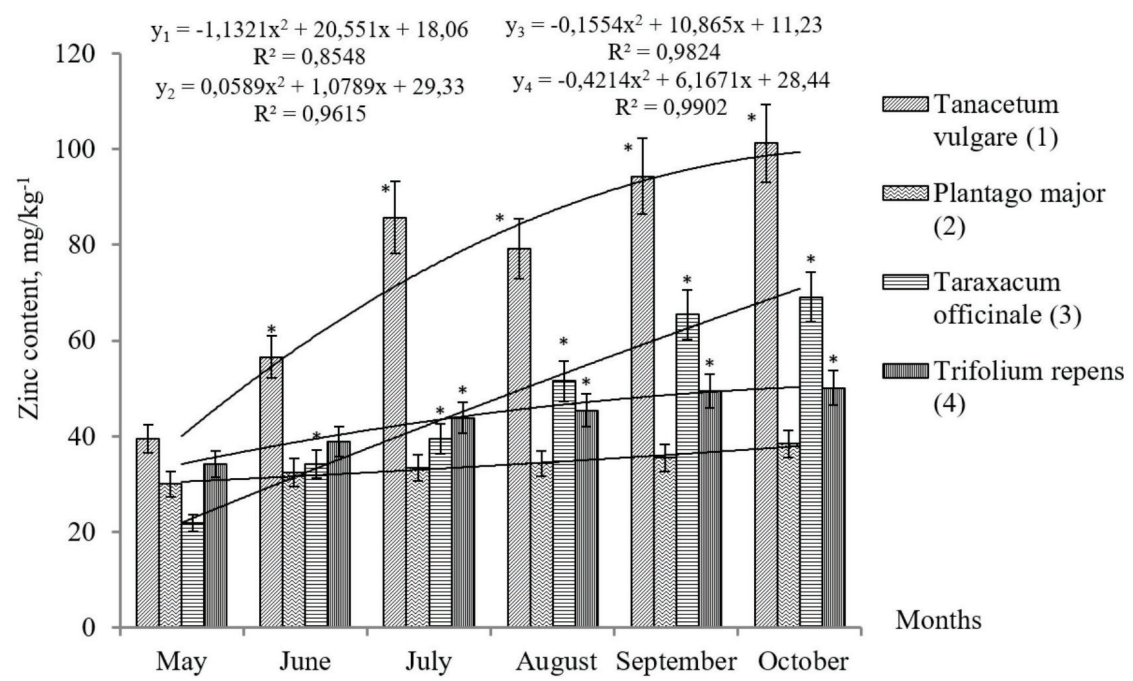

Figure 4: The zinc content in the leaves of herbaceous plants during the growing season in 2018 (industrial/ transport landscapes). The abscissa axis shows the growing season, months; the ordinate indicates zinc content, $\mathrm{mg} / \mathrm{kg}^{-1} ;-$ is a polynomial trend lines, degree -2 . Data are expressed as mean values \pm standard deviations. The content of elements was determined in three mixed plant samples in three analytical replicates. Due to the insignificant discrepancy between the analytical replicates, statistical processing of data was carried out only by taking into account biological replications $(n=3)$. * Significantly different from control values (May) $(\mathrm{p}<0.05$, Student's t-test). 


\section{Discussion}

\section{Zinc Content in Soil}

Analysis of $\mathrm{Zn}$ content in the soil of various functional areas of the city showed that metal concentration was observed in the range from 108.2 to $154.7 \mathrm{mg} / \mathrm{kg}^{-1}$. Maximum concentrations in soil samples were registered in trans-accumulative geochemical landscapes with oxidative conditions of soil formation and a weak alkaline reaction of the soil solution (IUTZ). Main reasons for $\mathrm{Zn}$ accumulation in the surface soil horizons of trans-accumulative landscapes included the proximity of the bedrock and the ability of trans-accumulative landscapes to absorb mineral and organic components with the formation of stable compounds (Maslennikov et al., 2018).

In general, the reasons for a rather strong pollution of soil grounds in urban ecosystems in Kaliningrad might be different, but the main factors were atmotechnogenic emissions from enterprises, road transport and peat fires (Maslennikov et al., 2018). Metal entry is also observed via precipitation (1 litre of rain and snow water accounted for $0.004-0.210$ $\mathrm{mg}$ of $\mathrm{Zn}$ ). Some $\mathrm{Zn}$ had entered the soil from mineral and organic fertilizers. One $\mathrm{kg}$ of mineral fertilizer contained a few to hundreds of milligrams of zinc, while in organic fertilizer, the amount ranges from tens to hundreds of milligrams (Maslennikov et al., 2018).

Another factor that increased the accumulation of $\mathrm{Zn}$ in urban soil was their alkalinization. A total of $88.0 \%$ of the urban area in Kaliningrad had been characterized by a weak alkaline reaction of the soil solution $(\mathrm{pH} 7.5-$ 8.0 ). And only $10.0 \%$ of urban soil had slightly acidic $\mathrm{pH}(5.5-6.5)$ and $2.0 \%$ of the soil were neutral (Maslennikov et al., 2018). Moreover, at a $\mathrm{pH}$ range of 5.5-7.0, $\mathrm{Zn}$ concentration in soil solution (soluble $\mathrm{Zn}$ ) decreased significantly by 30- to 45 -fold for each unit with an increase in soil pH (Gupta et al., 2016). In this regard, the removal and migration of many HMs, including $\mathrm{Zn}$, would be severely disrupted, which might lead to their accumulation in the upper soil horizon, causing the transformation of the soil geochemical structure in urban ecosystems of Kaliningrad.

\section{Zinc Content in Plants of Different Functional Zones of Kaliningrad}

A strong technogenic impact was manifested not only in the soil, but also in the vegetation of the city. Plants are one of the most sensitive indicators of technogenic pollution of the urban environment and are the first line of protection from precipitation deposition, including metalcontaining aerosols (Chupakhina et al., 2017; Maslennikov, 2020).

A quantitative analysis of metal content in the soil-plant system made it possible to reveal a number of accumulation patterns. An increase in the degree of urban ecosystem pollution had led to a change in the balance of metal accumulation in the soil-plant system. Under these conditions, plants were able to accumulate heavy metals in much larger quantities than similar species growing in an ecologically clean area. The number of pollutants absorbed by plants depended on the species' peculiarities, like biology, physiology and biochemistry, as well as on specificity of the elements, their concentration and the presence of antagonist metals (Gupta et al., 2016). Soil conditions, such as redox, geomorphological conditions and acid-base features of the upper soil layer, were also important for plant growth (Gupta et al., 2016).

An analysis of the ecological and geochemical characteristics of $\mathrm{Zn}$ accumulation in plant leaves had allowed us to identify the main factors contributing to an increase in its content in plant tissues, which were technogenic and geomorphological factors. With an increase in the atmo-technogenic pollution in the studied landscapes, there was an increase of metal content in plant tissues. Maximum level of $\mathrm{Zn}$ in leaves had been identified in IutL. For the majority of plants under study, the analysis of correlations between $\mathrm{Zn}$ concentrations in the soil and plants revealed a highly reliable degree of conjugacy between the levels of metal accumulation in soil and leaves $(r=0.86-0.99$, 
$\mathrm{p}<0.05)$. With the exception of Sambucus nigra $(\mathrm{r}=0.74, \mathrm{p}<0.05)$ and Plantago major $(\mathrm{r}=-0.13$, $\mathrm{p}=0.05)$ (Table 3$)$.

The accumulation of $\mathrm{Zn}$ in the studied plants was also significantly influenced by geochemical conditions of the territories. An increase of heteropolar and complexheteropolar compounds of $\mathrm{Zn}$ with organic matter was observed in the soil content of transaccumulative landscapes (IutL) (Chupakhina et al., 2017; Gupta et al., 2016). Data analysis of $\mathrm{Zn}$ content in plants growing in polluted areas (RZ, IutL) had allowed us to identify species which accumulated metal ions the most. Syringa vulgaris and Rosa rugosa were among species which actively accumulated $\mathrm{Zn}$. Metal content in the leaves of the former under conditions of severe soil pollution (like in IutL) exceeded the background by 3.9 times, and in the latter by 4.9 times. Seven out of 22 studied plant species showed an excess of $\mathrm{Zn}$ content in crop production. But in general, metal content in studied plants leaves did not reach maximum permissible values for their vital activity. For example, none of the plant samples exceeded critical (150-200 mg/ $\left.\mathrm{kg}^{-1}\right)$ and phytotoxic (400 $\left.\mathrm{mg} / \mathrm{kg}^{-1}\right) \mathrm{Zn}$ concentrations (Chupakhina et al., 2017; Gupta et al., 2016).

Despite the crucial role of $\mathrm{Zn}$ in metabolic reactions, elevated levels of this heavy metal ion can be phytotoxic. By replacing other divalent cations, $\mathrm{Zn}$ toxicity could interrupt vital metabolisms like photosynthesis, glycolysis and the electron transport chain (Cakmak, 2000; Cakmak, 2008; Disante et al., 2010). Excess $\mathrm{Zn}$ might interfere with genetic material through basic modifications, DNA breakage, rearrangements, depurination and epigenetic modifications. Crosstalk between $\mathrm{Zn}$ and other ions (mainly $\mathrm{Fe}, \mathrm{Ca}, \mathrm{P}$ ) could also modify physiological and molecular functions of both $\mathrm{Zn}$-stressed and Zn-deficit plants. In order to maintain a balance under $\mathrm{Zn}$-excess conditions, several homeostatic mechanisms are activated at genetic, cellular, organ and whole plant levels.

At genetic level, controlled expression of specific transport proteins in different cell layers of root and shoot made them act as check points in regulating the concentration of metal cations in relevant cell types. At cellular level, several low molecular weight metal chelators and metal-binding proteins participated in homeostatic regulation of species charged with $\mathrm{Zn}$ via cytosol and their subsequent storage in intracellular compartments. These metal chelators mainly included phytochelatins and metallothioneins. Furthermore, there had been reports on the sequestration of $\mathrm{Zn}$ as an organic acid complex in subcellular compartments (vacuole, cell wall, vesicles) (Verbruggen et al., 2009; Kramer, 2010; Sinclair \& Kramer, 2012; Samardjieva et al., 2015). The storage of $\mathrm{Zn}$ in vacuoles provided resistance to $\mathrm{Zn}$ toxicity.

Zinc content in plant leaves of urboecosystems would change during the vegetative period (May - October). The analysis of metal accumulation dynamics showed a minimum $\mathrm{Zn}$ content in leaves at the beginning of the growing season (May), which later increased with age and expansion of leaf blade area, reaching its maximum in October. The maximum $\mathrm{Zn}$ concentration was observed in the leaves of Populus nigra in October $\left(235.8 \pm 22.1 \mathrm{mg} / \mathrm{kg}^{-}\right.$ $\left.{ }^{1}\right)$. In the leaves of other plants, the metal level was much lower. The metal content in the leaves of the studied plants at the end of the growing season did not exceed its phytotoxic level (400 $\left.\mathrm{mg} / \mathrm{kg}^{-1}\right)$. The reason for the higher concentration of zinc in plant leaves at the end of the growing season was a significant contamination of soil with this metal and its gradual accumulation in plant tissues. The amount of metals in plants was influenced by seasonal dynamics, and their content at the beginning of the growing season could exceed two to three times the same indicator at the end of the growth period (Ilyin $\&$ Syso, 2001). Thus, an analysis of the metal storage capacity in 10 species of woody plants showed that in most species growing under polluted conditions, the $\mathrm{Zn}$ content increased by the end of the growing season. The content of other metals, on the contrary, might decrease (Sidorova, 2014). Other studies had shown that the dynamics of metal accumulation in the leaves of balsamic poplar (Populus balsamifera 
L.) was affected by proximity to the source of industrial emissions (Sterlitamak industrial site). Under these conditions, the $\mathrm{Zn}$ content in the leaves did not change until the middle of the growing season, but then intensified sharply. At the same time, under conditions of a relatively clean area (background), the $\mathrm{Zn}$ concentration in the leaves of these plants decreased by the end of the growing season (Sidorova, 2014).

Each element has a special physiological function in a plant, therefore the intensity of their absorption would not be the same. Plants, as they were well known, had a selective ability to accumulate elements. According to the type of chemical elements, mineral absorption could be divided into barrier-free (concentrating) and barrier (non-concentrating) plants (Chupakhina et al., 2017). Metal content in the ashes of barrier-free plants increased in proportion to its content in the environment. Barrier plants had a concentration threshold above which the absorption of elements would stop despite an increase in their content in the environment. The analysis of $\mathrm{Zn}$ absorption intensity in the background area showed that for the majority of plants under study, it was the element of weak absorption and average capture $(\mathrm{CBA}=0.3-0.8)$. For plants like Betula pendula $(\mathrm{CBA}=1.16)$ and Populus nigra $(\mathrm{CBA}=1.68), \mathrm{Zn}$ was strongly absorbed (Table. 3). For the majority of plant species, it was established that increasing $\mathrm{Zn}$ soil contamination had resulted in a significant decrease of the metal's CBA. There was an exception for Rosa rugosa and Syringa vulgaris, in which the intensity of element absorption was higher than in the background area (Table 3).

Plants had developed certain protective mechanisms to prevent an excessive supply of elements to their vegetative and generative organs. Barrier type element absorption involved a decrease in the intensity of metal absorption and an increase in its concentration in the soil (Chupakhina et al., 2017). Barrier-free plants would undergo an increase of CBA and a higher concentration threshold, beyond which there was no more absorption of the element.
The accumulation of $\mathrm{HMs}$ in plants depended not only on their species and physicochemical properties of the metal, but also on the mode of entry into the plants. The increase of atmotechnogenic pressure would cause the existing relationship between heavy metal content in soil and plants to be disrupted. Apparently, the growth of atmotechnogenic load would reinforce the importance of the foliar rout of pollutants entering the plants, and this increased the concentration of metals in plant leaves in contaminated zones (Chupakhina et al., 2017). The relationship between $\mathrm{Zn}$ content in the accumulative horizon of urban soil and in plant leaves could be described with linear equations. Corresponding linear regression coefficients, which were calculated by the least squares method, indicated an average increase in the $\mathrm{Zn}$ content in plants (in $\mathrm{mg} / \mathrm{kg}^{-1}$ ) with an increase in its concentration in the soil by $1 \mathrm{mg} / \mathrm{kg}^{-1}$. The corresponding regression $\mathrm{Zn}$ coefficients for trees, shrubs and herbaceous plants are given in Table 4.

The correlation of regression coefficients with zinc APC allowed us to estimate the average efficiency of metal bio-adsorption among typical representatives of the city's synanthropic flora. Thus, in woody plants, bioaccumulation efficiency was $0.07 \%$ for Tilia cordata, $0.08 \%$ for Acer platanoides, $0.41 \%$ for Betula pendula, and $1.1 \%$ for Populus nigra. As for shrubs, Zn bioaccumulation efficiency was $1.24 \%$ for Syringa vulgaris, $1.17 \%$ for Rosa rugosa, $0.74 \%$ for Viburnum opulus, $0.30 \%$ for Ribes alpinum, $0.22 \%$ for Symphoricarpos rivularis, $0.18 \%$ for Philadelphus coronarius, $0.13 \%$ for Hippophae rhamnoides, 0.12 $\%$ Berberis vulgaris, $0.11 \%$ for Ligustrum vulgare, $0.05 \%$ for Sambucus nigra and 0.03 $\%$ for Spirae vanhouttei. Values for herbaceous plants were the following: Tanacetum vulgare (0.49 \%), Trifolium pratense $(0.42 \%)$, Achillea millefolium $(0.41 \%)$, Taraxacum officinale (0.19\%), Trifolium repens $(0.17 \%)$, Dactylis glomerata $(0.15 \%)$, Plantago major $(0.01 \%)$. 
Table 3: The intensity of zinc absorption by leaves of trees, shrubs and herbaceous plants in various functional zones in Kaliningrad

\begin{tabular}{|c|c|c|c|}
\hline \multirow[b]{2}{*}{ Species } & \multicolumn{3}{|c|}{ The coefficient of biological absorption (CBA) } \\
\hline & RecZ & $\mathbf{R Z}$ & IUTZ \\
\hline \multicolumn{4}{|c|}{ Tree species } \\
\hline Populus nigra $\mathrm{L}$. & 1.68 & 0.97 & 0.96 \\
\hline Betula pendula Roth & 1.16 & 0.59 & 0.52 \\
\hline Acer platanoides L. & 0.67 & 0.28 & 0.24 \\
\hline Tilia cordata Mill. & 0.45 & 0.19 & 0.17 \\
\hline \multicolumn{4}{|c|}{ Shrubs } \\
\hline Sambucus nigra L. & 0.61 & 0.27 & 0.21 \\
\hline Symphoricarpos rivularis Suksdorf. & 0.50 & 0.25 & 0.24 \\
\hline Syringa vulgaris L. & 0.49 & 0.63 & 0.61 \\
\hline Viburnum opulus 'Roseum' & 0.49 & 0.38 & 0.45 \\
\hline Ligustrum vulgare $\mathrm{L}$. & 0.41 & 0.19 & 0.17 \\
\hline Philadelphus coronarius $\mathrm{L}$. & 0.40 & 0.20 & 0.20 \\
\hline Ribes alpinum $\mathrm{L}$. & 0.40 & 0.22 & 0.25 \\
\hline Spirae vanhouttei (Briot.) Zab. & 0.37 & 0.16 & 0.13 \\
\hline Rosa rugosa Thunb. & 0.35 & 0.50 & 0.55 \\
\hline Berberis vulgaris L. & 0.35 & 0.16 & 0.16 \\
\hline Hippophae rhamnoides L. & 0.29 & 0.15 & 0.14 \\
\hline \multicolumn{4}{|c|}{ Herbs } \\
\hline Trifolium pratense $\mathrm{L}$. & 0.78 & 0.46 & 0.40 \\
\hline Plantago major $\mathrm{L}$. & 0.70 & 0.29 & 0.22 \\
\hline Trifolium repens $\mathrm{L}$. & 0.57 & 0.28 & 0.25 \\
\hline Tanacetum vulgare $\mathrm{L}$. & 0.55 & 0.34 & 0.37 \\
\hline Achillea millefolium $\mathrm{L}$. & 0.51 & 0.33 & 0.32 \\
\hline Taraxacum officinale Wigg.s.l. & 0.47 & 0.24 & 0.22 \\
\hline Dactylis glomerata L. & 0.41 & 0.19 & 0.19 \\
\hline
\end{tabular}

Note: RZ stands for recreational zones (background), RZ for residential zones, and IUTZ for industrial/utility/ transport zones.

The correlation of linear regression coefficients with the metal APC might be useful in a preliminary assessment of soil phytoremediation effectiveness, since it suggested the proportion of metal APC that was utilized by plants during one growing season. Such analysis would help to initiate the development of phytoremediation technologies that could be adapted in the Kaliningrad region, i.e. the selection of plants - remediators from the representatives of local phytophlora. This would also offer prospects for experimental development of phytoremediation technologies in the region.

\section{Conclusion}

High $\mathrm{Zn}$ content was found in the accumulative horizon of soil in main functional zones of the city (ARZ, RZ, and IUTZ). Maximum metal 
Table 4: The relationship between zinc content (x) in the soil and plant leaves (y)

\begin{tabular}{|c|c|c|c|}
\hline Species & $\begin{array}{c}\text { Linear regression } \\
\text { equation }\end{array}$ & $\mathbf{R}^{2 *}$ & $\mathbf{R}^{* *}$ \\
\hline \multicolumn{4}{|c|}{ Tree species } \\
\hline Populus nigra $\mathrm{L}$. & $y=0.6034 x+52.045$ & 0.9816 & 0.99 \\
\hline Betula pendula Roth & $y=0.2273 x+45.998$ & 0.9996 & 0.99 \\
\hline Acer platanoides $\mathrm{L}$. & $y=0.0421 x+30.846$ & 0.9404 & 0.97 \\
\hline Tilia cordata Mill. & $y=0.0398 x+19.935$ & 0.9141 & 0.96 \\
\hline \multicolumn{4}{|c|}{ Shrubs } \\
\hline Syringa vulgaris L. & $y=0.6828 x-8.8695$ & 0.9965 & 0.99 \\
\hline Rosa rugosa Thunb. & $y=0.6421 x-14.972$ & 0.9972 & 0.99 \\
\hline Viburnum opulus 'Roseum' & $y=0.4078 x+2.6959$ & 0.9482 & 0.97 \\
\hline Ribes alpinum $\mathrm{L}$. & $y=0.1641 x+10.47$ & 0.8723 & 0.93 \\
\hline $\begin{array}{l}\text { Symphoricarpos rivularis } \\
\text { Suksdorf. }\end{array}$ & $y=0.1196 x+18.285$ & 0.9579 & 0.98 \\
\hline Philadelphus coronarius L. & $y=0.0984 x+14.304$ & 0.9006 & 0.95 \\
\hline Berberis vulgaris L. & $y=0.066 x+13.488$ & 0.9053 & 0.95 \\
\hline Hippophae rhamnoides L. & $y=0.069 x+10.525$ & 0.9794 & 0.99 \\
\hline Ligustrum vulgare L. & $y=0.0595 x+17.039$ & 0.9507 & 0.98 \\
\hline Sambucus nigra L. & $y=0.0276 x+29.241$ & 0.5548 & 0.74 \\
\hline Spirae vanhouttei (Briot.) Zab. & $\mathrm{y}=0.0148 \mathrm{x}+17.915$ & 0.7383 & 0.86 \\
\hline \multicolumn{4}{|c|}{ Herbs } \\
\hline Tanacetum vulgare $\mathrm{L}$. & $y=0.2716 x+12.609$ & 0.9344 & 0.97 \\
\hline Achillea millefolium $\mathrm{L}$. & $y=0.2235 x+14.051$ & 0.9929 & 0.99 \\
\hline Trifolium pratense $\mathrm{L}$. & $y=0.2334 x+27.432$ & 0.9911 & 0.99 \\
\hline Taraxacum officinale Wigg.s.1. & $y=0.1072 x+17.576$ & 0.9831 & 0.99 \\
\hline Trifolium repens $\mathrm{L}$. & $y=0.0955 x+23.158$ & 0.9936 & 0.99 \\
\hline Dactylis glomerata $\mathrm{L}$. & $y=0.0798 x+15.678$ & 0.7866 & 0.89 \\
\hline Plantago major L. & $y=-0.0034 x+35.107$ & 0.0158 & -0.13 \\
\hline
\end{tabular}

Note:* Approximate reliability value. ${ }^{* *}$ Correlation coefficient.

content was observed in IutL and residential multistore areas with increased transport load. Background content of $\mathrm{Zn}$ in plant leaves did not depend on their life form. In natural conditions, active accumulators of include Betula pendula and Populus nigra, Sambucus nigra (among shrubs), and Trifolium pratense (among herbaceous plants). The highest absorption rates in plants growing in polluted areas were typical for Syringa vulgaris, Rosa rugosa and Populus nigra. These species might be useful for the potential phytoremediation of areas moderately polluted with $\mathrm{Zn}$. The majority of plants under study showed an increase of $\mathrm{Zn}$ content in the leaves by the end of the growing season, and they demonstrated a highly reliable correlation between the levels of metal accumulations in the soil and leaves $(\mathrm{r}=0.86-0.99, \mathrm{p}<0.05)$. Plant species capable of limiting the entry of $\mathrm{Zn}$ from the environment were identified. To conclude, the study of $\mathrm{Zn}$ content in the soil-plant system was an important step in assessing the risk of 
potential transfer in the soil-plant-human chain, and the results could be used to improve the ecosystem and human health, beside planning, assessing risks and making decisions on environmental management in the region.

\section{Acknowledgements}

This research was supported by the Russian Academic Excellence Project at the Immanuel Kant Baltic Federal University.

\section{References}

Bailey, S., Thompson, E., Nixon, P. J., Horton, P., Mullineaux, C. W., Robinson, C., \& Mann, N. H. (2002). A critical role for the Var2 FtsH homologue of Arabidopsis thaliana in the photosystem II repair cycle in vivo. The Journal of Biological Chemistry, 277(3), 2006-2011.

Baran, A., Wieczorek, J., Mazurek, R., Urbański, K., \& Klimkowicz-Pawlas, A. (2018). Potential ecological risk assessment and predicting zinc accumulation in soils. Environmental Geochemistry and Health, 40(1), 435-450.

Broadley, M. R., White, P. J., Hammond, J. P., Zelko, I., \& Lux, A. (2007). Zinc in plants. New Phytologist, 173(4), 677-702.

Brezinova, T., \& Vymazal, J. (2015). Evaluation of heavy metals seasonal accumulation in Phalaris arundinacea in a constructed treatment wetland. Ecological Engineering, 79, 94-99.

Cakmak, I. (2000). Possible roles of zinc in protecting plant cells from damage by reactive oxygen species. New Phytologist, 146(2), 185-205.

Cakmak, I. (2008). Enrichment of cereal grains with zinc: Agronomic or genetic biofortification? Plant and Soil, 302(1), $1-17$.

Catlett, K. M., Heil, D. M., Lindsay, W. L., \& Ebinger, M. H. (2002). Soil chemical properties controlling zinc $\left(2^{+}\right)$activity in
18 Colorado soils. Soil Science Society of America Journal, 66, 1182-1189.

Chupakhina, G. N., Maslennikov, P. V., Mosina, L. V., Skrypnik, L. N., Dedkov, V. P., Chupakhina, N. Yu., \& Feduraev, P. V. (2017). Accumulation of biogenic metals in the plants of urbanised ecosystems in the city of Kaliningrad. Research Journal of Chemistry and Environment, 21(1), 9-17.

Clemens, S., Palmgren, M. G., \& Kramer, U. (2002). A long way ahead: Understanding and engineering plant metal accumulation. Trends in Plant Science, 7(7), 309-315.

Das, S., \& Green, A. (2013). Importance of zinc in crops and human health. Journal of SAT Agricultural Research, 11, 1-7.

Delavar, M. A., \& Safari, Y. (2016). Spatial distribution of heavy metals in soils and plants in Zinc Town, northwest Iran. International Journal of Environmental Science and Technology, 13, 297-306.

Disante, K. B., Fuentes, D., \& Cortina, J. (2010). Response to drought of Zn-stressed Quercus suber L. seedlings. Environmental and Experimental Botany, 70, 96-103.

Guo, G., Wu, F., Xie, F., \& Zhang, R. (2012). Spatial distribution and pollution assessment of heavy metals in urban soils from southwest China. Journal of Environmental Sciences, 24, 410-418.

Gupta, N., Ram, H., \& Kumar, B. (2016). Mechanism of zinc absorption in plants: Uptake, transport, translocation and accumulation. Reviews in Environmental Science and Bio/Technology, 15(1), 89-109.

Hani, A., \& Pazira, E. (2011). Heavy metals assessment and identification of their sources in agricultural soils of Southern Teheran. Environmental Monitoring Assessment, 176, 677-691.

Hansch, R., \& Mendel, R. R. (2009). Physiological functions of mineral micronutrients $(\mathrm{Cu}, \mathrm{Zn}, \mathrm{Mn}, \mathrm{Fe}, \mathrm{Ni}, \mathrm{Mo}$, $\mathrm{B}, \mathrm{Cl})$. Current Opinion in Plant Biology, 12(3), 259-266. 
Hambidge, M. (2000). Human zinc deficiency. The Journal of Nutrition, 130(5), 13441349.

Hotz, C., Brown, K. H. (2004). Assessment of the risk of zinc deficiency in populations and options for its control. Food and Nutrition Bulletin, 25(1), 94-204.

Ilyin, V. B., \& Syso, A. I. (2001). Trace elements and heavy metals in soils and plants of the Novosibirsk region. Novosibirsk Publisher: SB RAS.

Kabata-Pendias, A. (2011). Trace elements in soil and plants. Boca Raton, FL: CRC Press.

Kramer, U. (2010). Metal hyper-accumulation in plants. The Annual Review of Plant Biology, 61(1), 517-534.

Lago-Vila, M., Rodriguez-Sejio, A., ArenasLago, D., Andrade, L., \& Vega, M. (2017). Heavy metal content and toxicity of mine and quarry soils. Journal of Soils and Sediments, 17, 1331-1348.

Lin, C. W., Chang, H. B., \& Huang, H. J. (2005). Zinc induces mitogenactivated protein kinase activation mediated by reactive oxygen species in rice roots. Plant Physiology and Biochemistry, 43, 963-968.

Lopez, M., Ellis, D. R., \& Grusak, M. A. (2005). Effect of zinc and manganese supply on the activities of superoxide dismutase and carbonic anhydrase in Medicago truncatula wild type and raz mutant plants. Plant Science, 168, 1015-1022.

Maslennikov, P. V., Chupakhina, G. N., Skrypnik, L. N., Feduraev, P. V., \& Melnik, A. S. (2018). Assessment of the antioxidant potential of plants in urban ecosystems under conditions of anthropogenic pollution of soils. Russian Journal of Ecology, 49(5), 384-394.

Maslennikov, P. V. (2020). Ecological and geochemical evaluation of ecosystems of the Curonian Spit (Russia). International
Journal of Environmental Studies, 77(3), 447 - 463.

Nielsen, F. H. (2012). History of zinc in agriculture. Advances in Nutrition, 3(6), 783-789.

Obrador, A., Novillo, J., \& Alvarez, J. M. (2003). Mobility and availability to plants of two zinc sources applied to a calcareous soil. Science Society of America Journal, 67(2), 564-572.

Olaniran, A. O., Balgobind, A., \& Pillay, B. (2013). Bioavailability of heavy metals in soil: Impact on microbial biodegradation of organic compounds and possible improvement strategies. International Journal of Molecular Sciences, 14(5), 10197-10228.

Peck, A. W., \& McDonald, G. K. (2010). Adequate zinc nutrition alleviates the adverse effects of heat stress in bread wheat. Plant and Soil, 337(1), 355-374.

Phetsombat, S., Kruatrachue, M., Pokethitiyook, P., \& Upatham, S. (2006). Toxicity and bioaccumulation of cadmium and lead in Salvinia cucullata. Journal of Environmental Biology, 27(4), 645-652.

Romero-Freire, A., García Fernandez, I., Simon Torres, M., Martínez Garzon, F. J., \& Martín Peinado, F. J. (2016). Long-term toxicity assessment of soils in a recovered area affected by a mining spill. Environmental Pollution, 208, 553-561.

Rout, G. R., \& Das, P. (2003). Effect of metal toxicity on plant growth and metabolism: I. Zinc. Agronomie, 23, 3-11.

Sadeghzadeh, B. (2013). A review of zinc nutrition and plant breeding. Journal of Soil Science and Plant Nutrition, 13(4), 905927.

Samardjieva, K. A., Tavares, F., \& Pissarra, J. (2015). Histological and ultrastructural evidence for $\mathrm{Zn}$ sequestration in Solanum nigrum L. Protoplasma, 252(1), 345-357. 
Sidorova, O. V. (2014). Features of linden damage by the small-leaved complex of arthropods - phylophages in Izhevsk. [Cand. Sci. (Biol.) Dissertation, Izhevsk].

Sinclair, S. A., \& Kramer, U. (2012). The zinc homeostasis network of land plants. Biochimica et Biophysica Acta - Molecular Cell Research, 1823(9), 1553-1567.

Verbruggen, N., Hermans, C., \& Schat, H. (2009). Molecular mechanisms of metal hyper-accumulation in plants. New Phytologist, 181(4), 759-776.

Vymazal, J., \& Brezinova, T. (2015). Heavy metals in plants in constructed and natural wetlands: Concentration, accumulation and seasonality. Water Science \& Technology, 71(2), 268-276.

White, P. J. (2012). Heavy metal toxicity in plants. In Shabala S. (Ed.), Plant stress physiology. CABI, Wallingford. 